\title{
Correlated Factors With Psychological Resilience and Problem Solving Skills of Nursing Students
}

\author{
Hemşirelik Öğrencilerinin Psikolojik Dayanıklılık ve \\ Problem Çözme Becerileri ile iliş̧kili Faktörler
}

\author{
Melike ERTEM ${ }^{1}$, Gülay YILMAZ², Yasemin YILDIRIM USTA³ \\ 1 İzmir Katip Çelebi Üniversitesi Sağlık Bilimleri Fakültesi Hemşirelik Bölümü Hemşirelikte Öğretim Anabilim Dalı \\ • melike_yonder@hotmail.com• ORCID > 0000-0002-7039-3650 \\ ${ }^{2}$ Yozgat Bozok Üniversitesi Sağlık Bilimleri Fakültesi Hemşirelik Bölümü Ruh Sağlı̆̆ı ve Hastalıkları Hemşireliği \\ Anabilim Dalı \\ • gulay.yilmaz22@gmail.com• ORCID > 0000-0002-1386-9018
}

${ }^{3}$ Bolu Abant İzzet Baysal Üniversitesi, Bilimleri Fakültesi, Hemşirelik Bölümü Iç Hastalıkları Hemşireliği Anabilim Dalı • yildirim_y@ibu.edu.tr• ORCiD > 0000-0003-2378-4875

Makale Bilgisi / Article Information

Makale Türü / Article Types: Araştırma Makalesi / Research Article Geliş Tarihi / Received: 20 Mayıs / May 2021 Kabul Tarihi / Accepted: 7 Ekim / October 2021

YIl/Year: 2021 | Cilt - Volume: 6 | Sayı - Issue: 3 | Sayfa / Pages: 507-524

Atıf/Cite as: Ertem, M., Yılmaz, G. ve Yıldırım Usta, Y. “Correlated Factors With Psychological Resilience And Problem Solving Skills Of Nursing Students - Hemşirelik Öğrencilerinin Psikolojik Dayanıkulık ve Problem Çözme Becerileri ile ilişkili Faktörler". Samsun Sağlık Bilimleri Dergisi- Journal of Samsun Health Sciences 6(3), Aralık 2021: 507-524. https://doi.org/10.47115/ jshs.940097

Sorumlu Yazar: Melike ERTEM

Copyright @ Published by Ondokuz Mayıs Üniversitesi, Sağlık Bilimleri Fakültesi - Ondokuz Mayıs University, Faculty of Health Sciences, Samsun, Turkey. All rights reserved. 


\section{CORRELATED FACTORS WITH PSYCHOLOGICAL RESILIENCE AND PROBLEM SOLVING SKILLS OF NURSING STUDENTS}

\section{ABSTRACT:}

Objectives: The aim of this study is to determine the factors affecting resilience and problem-solving skills in nursing students and correlation between resilience and problem-solving skills.

Methods: This cross sectional-correlational study was conducted at the Faculty of Health Sciences in a public university. The haphazard sampling method was used. The population of this study consists of 293 nursing students. Study data were collected by the researchers through "Personal Information Form, Psychological Resilience Scale and Problem Solving Inventory”.

Results: Participants' average age was $20.83 \pm 1.75$ and $81.9 \%$ of them were female. It was determined that there was a statistically significant relationship between sub-dimensions of Psychological Resilience Scaleand Problem Solving Inventory.

Conclusion: Research results showed that there is a significant relationship between students' psychological resilience and problem solving skills. It is of important that nurse educators and school administrators plan activities such as mentoring and group education sessions, plan psychological counselling and training programs, set clear organizational strategies to increase students' problem-solving skill methods and resilience.

Keywords: Nursing; Problem solving; Resilience; Students

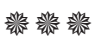

\section{HEMŞIRELIK ÖĞRENCILERININ PSIKOLOJIK DAYANIKLILIK VE PROBLEM ÇÖZME BECERILERI ILE ILIŞKILI FAKTÖRLER}

\section{ÖZ:}

Amaç: Bu çalışmanın amacı; hemşirelik öğrencilerinde psikolojik dayanıklılığı ve problem çözme becerilerini etkileyen faktörlerin belirlenmesi ve aralarındaki ilişkinin incelenmesidir.

Yöntem: Tanımlayıcı-ilişki arayıcı niteliğindeki araştırma bir devlet üniversitesinin Sağlık Bilimleri Fakültesi’nde yürütülmüştür. Araştirmada gelişigüzel ör- 
nekleme yöntemi kullanılmış olup, örneklemi eğitim alan 293 hemşirelik öğrencisi oluşturmaktadır. Araştırma verileri araştırmacılar tarafından "Kişisel Bilgi Formu, Psikolojik Dayanıklılık Ölçeği ve Problem Çözme Envanteri” aracılığıyla toplanmıştır.

Bulgular: Katılımcıların yaş ortalaması $20.83 \pm 1.75$ olup, \%81.9’u kadındır. Yapılan istatistiksel değerlendirmede Psikolojik Dayanıklılık Ölçeği ve "Problem Çözme Envanteri ile alt boyutları arasında istatistiksel olarak anlamlı bir ilişki saptanmıştır.

Sonuç: Araştırmada öğrencilerin psikolojik dayanıklılıkları ile problem çözme becerileri arasında istatiksel olarak anlamlı bir ilişki saptanmıştır. Hemşire eğitmenlerinin ve okul yöneticileri tarafından mentorluk ve grup eğitimi, psikolojik danışma ve eğitim programlarının planlanması, öğrencilerin problem çözme beceri yöntemlerini ve dayanıklılığını artırmak için belirli kurumsal stratejileri belirlemesi önemlidir.

Anahtar Kelimeler: Hemşirelik; Problem çözme; Psikolojik dayanıklılı; Öğrenci

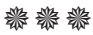

\section{INTRODUCTION}

It is seen that occupational members working in the field of health face stressful situations such as working environment, team members from different professions and their experience levels, providing service for many patients in a limited time and making critical decisions, and it is argued that the most affected field of occupation affected by stressors is nursing (Kelly \& Lefton, 2017; Kester \& Holly, 2018; Schmidt \& Haglund, 2017). Nurses need to have resilience in order to be able to cope effectively with stressful situations, adapt to these things and maintain their mental health (Kester \& Holly, 2018). In this regard, the aim of nursing education is to teach and gain the professional characteristics of nursing to the student, and to prepare him/her to professional life in the most correct way by supporting his/ her personal development (Çelikkalp ve ark, 2010; Ergöl ve Kürtüncü, 2013). For this reason, it is crucial to develop the resilience of students receiving nursing education so that they can adapt and cope effectively with the academic problems they face while studying and the difficulties required by the profession (Stephens, 2015).

The concept of resilience is defined as the capacity of an individual to continue his/her development process and adapt to negative experiences (Arslan, 2015). In addition to this capacity, there are many ways, some of which are predominant, to support people's resilience in the face of annoying situations. These are as follows; 
perceived social support, personal control degree and ability to use social relations, individuals' focusing their time, energy and duties on situations they have within their sphere of influence, experience of self-regulation of negative emotions and transforming them into positive emotions, cognitive flexibility, the ability to solve negative situations and the ability to take action directly to solve the problem, ability to engage in a manner consistent with values and life priorities that reflect their expectations in the future (Arslan, 2015; Meichenbaum, 2009).

An individual acquires some qualifications in his/her struggle with distressing situations in the process of resilience. These qualities, which are called positive results or in other words, competences, are the characteristics that individuals acquire as a result of minimizing risk factors due to the protective factors they have (K1lıç, 2014). Positive situation or result occurring in such cases supports an individual's fulfilling his/her subsequent developmental tasks successfully and ensures that s/he is qualified as a "healthy child" or "healthy adult" (Gündaş, ve Koçak, 2015). This process is shaped as a result of an individual's coping with problems effectively that s/he faced. At this point, effective problem-solving skills of nursing candidates are important.

Problem-solving is a complex process involving a series of cognitive, emotional and behavioural activities that an individual displays in order to solve problems creating obstacles, stressing out, waiting for solution,s/he may encounter during his/her life. The problem-solving process begins when a difference is detected between wished and current situation, and includes bringing all possible solutions together related to a topic and carrying out all professional practices. It is urged in the literature that problem-solving skills are necessary for an individual to lead a healthy life and to maintain mental health, and it was emphasized that there is a close relationship between problem-solving skills and mental health (Asimopoulos et al., 2018; Ranjbar et al., 2013).

Problem-solving is an important but less understood characteristic of nursing. A through and correct understanding of this process improves the quality of care and develops professional skills. Quality patient care requires recognizing and solving patients' health problems (Erol et al., 2016; Ghosh, \& Sobek, 2015; Thomas et al., 2018). The way to achieve this is to use the problem-solving approach. Nurses are expected to have good problem-solving skills in professions such as nursing providing service to people directly. Because this is a necessity and nursing education programs aim to gain this skill (Ançel, 2016; Bayındır, \& Olgun, 2015). It is also known that the training of problem-solving is of significant effect on problem-solving skills (Ançel, 2016). For this reason, it is very important that nursing students, who are health professionals of the future, are competent to cope with stressors and clinical issues since it has an effect on the health care quality. Because 
nurses with high problem-solving skills can cope with negative feelings and thoughts, generate healthy solutions and improve the quality of health care services provided.

Stress/difficulty is one of the most common risk factors of resilience. With the addition of academic stressors to daily life stressors, nursing students can perceive their stress in different intensity according to their past experiences and existing coping skills. Although some of the students express their stress verbally, some may not take any action against this risk factor, and this may cause students to live many negative results in time. Students are vulnerable to the negative effects of stress in nursing education programs, involving late adolescents and young adults, due to their inadequate problem-solving experiences (Stephens, 2015).

Patient care areas are environments involving many situations causing stress such as providing individualized care for people with different demographic information and socio-cultural backgrounds, communication barriers or difficulties, witnessing death, providing care for patients in terminal period, and exposure to infectious diseases. The student performing clinical practice in this environment is at risk due to cognitive dissonance s/he lives in transferring theoretical knowledge s/he obtained into practice and the stress caused by horizontal/vertical violence (Stephens, 2015). Nursing students also experience academic problems such as inadequate educational environment, lack of care and support (Atasoy \& Sütütemiz, 2014; Yıldırım, Calt \& Ardahan, 2019).

Since many nursing students are unprepared for clinical practice regulations, physical and emotional competence required by patient care, and negative interactions that they live with health professionals and/or academic staff, they adopt responses in line with the situation or are defeated by negative effects left on them (Stephens, 2015). As stress continues to the detriment of nursing students and affects their academic lives, students have to improve their resilience in order to tolerate problems and difficulties (Lopez et al., 2018; Thomas, \& Revell, 2016). Resilience will contribute students in achieving successful results in the future, protecting and improving their health and long-term career life by enabling them to face risk factors, and thus develop by facing events related to life and challenges by means of hope and optimism (Stephens, 2015). Therefore, risk and protective factors of nursing students should be determined during nursing education and their resilience should be focused on. It has been found out that the number of studies conducted on the resilience of nursing students is very few and there is no study examining its relationship with problem-solving skills.

This study aimed to determine the factors affecting psychological resilience and problem-solving skills in nursing students and correlation between resilience and 
problem-solving skills.

\section{Research Questions}

-Is there a correlation between the psychological resilience and problem-solving skills of nursing students'?

-What are the socio-demographic characteristics affecting nursing students' psychological resilience and problem-solving skills?

\section{METHODS}

\section{Type of Research}

This research was planned as a cross-sectional, correlational screening model to determine the correlation between resilience and problem-solving skills in nursing students.

\section{Place of Research}

The research was conducted with the students of the Faculty of Health Sciences, Department of Nursing in a public university.

\section{Population and Sample of Research}

The population of this research was determined to be total 412 students studying at the Faculty of Health Sciences Department of Nursing in a public university. Haphazard sampling method was used. Power analysis was performed in $\mathrm{G}^{\star}$ Power 3.1.3 program and sample size was determined. The power of the test was found to be $.99(99 \%)$, with Type I error= .05. Data were collected by applying research materials on 293 students, wishing to participate voluntarily in the research, in the Nursing Department of Health Sciences Faculty with the permission of the instructor before the main branch course of each class according to the school time table of the students. The research materials were filled out by students approximately in 10 minutes.

\section{Data Collection Tools}

Questionnaire and scale method, which are of self-report methods, were used to collect the research data. 


\section{Personal Information Form}

This form was developed by researchers and questions were related to sociodemographic characteristics of students such as age, gender, class, current place of residence, working status, family structure, number of siblings, income status of their families, how communication and relationships are in their families, educational background and professions of parents, opinions about parents' attitudes and reason for choosing profession s/he does when encountering a problem, type of personality, how his/her communication and relationships are with his/her surrounding, case of experiencing life events.

\section{Psychological Resilience Scale (PRS)}

Psychological Resilience Scale (PRS) involving 21 items, developed by Terzi (2016) in order to determine resilience level, consists of 21 items and three sub-dimensions indicating the beliefs of the individual about himself/herself and his/her life (Terzi, 2016). PRS is a 5-point Likert-type scale scored between (0) strongly disagree, (4) strongly agree. PRS includes direct expressions and reverse expressions, and items 2 and 15 are scored in reverse direction. The scale consisted of 21 items and three sub-dimensions. These dimensions were called Self-Commitment (PRS$\mathrm{SC}$ ), Control (PRS-C) and Challenging (PRS-CH) in the light of literature. General resilience score is obtained after scoring three sub-dimensions separately. While high scores of scale indicate that resilience reduces, low scores refer that resilience increases. The Cronbach alpha reliability coefficient for the whole scale is .76.

\section{Problem Solving Inventory (PSI)}

Şahin, Şahin and Heppner adapted the Turkish adaptation of the Problem Solving Inventory (PSI) in 1993 (Şahin et al., 1993). The inventory is a type of self-assessment scale applied to adolescent-adults and it evaluates that problem-solving behaviour and approaches. PSI consisted of 35 items and it is a Likert-type scale which scored between (1) I always behave like this, (6) I never behave like this. Negative items are reversed in scoring (14 items). The lowest score that can be obtained from the scale is 32 and the highest score is 192. While high scores received from the inventory indicate that individual perceives himself/herself as ineligible in terms of problem-solving skills, achieving low score suggests that individual perceives himself/herself as eligible in problem-solving. The scale consists of three sub-dimensions. The first one of this is "Problem Solving Confidence" referring one's belief in his/her ability to solve new problems (PSI-PSC, 11 items). The second one is "The Manner of Approach-Avoidance" expressing to review the initial problem-solving efforts for future reference and to investigate actively for alternative solutions (PSI-MAA, 16 items). Finally, the dimension of "Personal Control" related to people's ability to maintain control in problematical situations 
(PSI-PC, 6 items). In this research, Cronbach's alpha coefficient was calculated to be .82 .

\section{Data Analysis}

Parametric methods were used in order to assess the relationship between the parameters in the introduction form and the scale and subscales through SPSS 21 statistical program. Kolmogorov-Smirnov analysis was performed to check normal distribution.Since total scores of the scales and sub-scales were accepted as dependent variables, OneWay ANOVA was used for multiple variables and Independent-Samples t-test was used in binary variables to determine whether the independent variables affect the scales and sub-dimensions of the scales. Significance value was accepted as $\mathrm{p}<.05$. Post-Hoc Multiple Comparisons Tukey test was administrated in order to determine the group creating difference in the variables with significant difference and more than two groups. Pearson correlation method was used between the scale and its subscales. Other variables are given as numbers and percentages.

\section{Ethical Consideration}

This study was approved by the Institutional Review Board (2017-KAEK189_2018091206). Written permission were obtained from the nursing department of the university. Students participating in this study were informed about the study before data collection process and their informed written consents were received. The research was conducted in compliance with the Helsinki Declaration.

\section{Limitations}

This research took place only in a nursing faculty, a fact that limits the generalization of the results to the general population of nursing students. And the results are limited to this research participants' answers.

\section{RESULTS}

\section{Assessment of Sociodemographic Characteristics of Students}

The average age of the participants was $20.83 \pm 1.75$ years. $81.9 \%$ of the participants were women, $88.1 \%$ came from another province, $76.8 \%$ were in nuclear family structure and $31.1 \%$ defined their family attitude as protective. $72.4 \%$ of the students lived in dormitories. Moreover, economic level of $79.9 \%$ of the participants was medium, $85.3 \%$ of them had health insurance, $11.9 \%$ of them had health problems, $54.3 \%$ of those stating that they had health problems were still receiving treatment and $48.8 \%$ of them indicated their success status as good (Table 1). 
Table 1. Sociodemographic characteristics of students

\begin{tabular}{|c|c|c|}
\hline Introductory Information & Number & $\%$ \\
\hline \multicolumn{3}{|l|}{ Grade } \\
\hline 1 & 78 & 26.6 \\
\hline 2 & 93 & 31.7 \\
\hline 3 & 77 & 26.3 \\
\hline 4 & 45 & 15.4 \\
\hline \multicolumn{3}{|l|}{ Age } \\
\hline 18-20 ages & 127 & 43.3 \\
\hline $21-23$ ages & 145 & 49.5 \\
\hline 24 and Above Ages & 21 & 7.2 \\
\hline \multicolumn{3}{|l|}{ Gender } \\
\hline Female & 240 & 81.9 \\
\hline Male & 53 & 18.1 \\
\hline \multicolumn{3}{|c|}{ Status of Coming from Out of City } \\
\hline Yes & 258 & 88.1 \\
\hline No & 35 & 11.9 \\
\hline Family Type & 154 & 57.5 \\
\hline Nuclear Family & 225 & 76.8 \\
\hline Extended Family & 60 & 20.5 \\
\hline Single Parent Family & 8 & 2.7 \\
\hline \multicolumn{3}{|l|}{ Family Structure } \\
\hline Authoritarian & 37 & 12.6 \\
\hline Democratic & 55 & 18.8 \\
\hline Inconsistent & 9 & 3.1 \\
\hline Extreme Oppressive & 8 & 2.7 \\
\hline Indifferent and Unmindful & 4 & 1.4 \\
\hline Protective & 91 & 31.1 \\
\hline Tolerant & 89 & 30.4 \\
\hline \multicolumn{3}{|l|}{ Current Residence } \\
\hline At Home with Family/Relatives & 28 & 9.2 \\
\hline At Home with Friends & 53 & 18.4 \\
\hline In Dormitory/Pension & 212 & 72.4 \\
\hline \multicolumn{3}{|l|}{ Economic Level } \\
\hline Poor & 29 & 9.9 \\
\hline Medium & 234 & 79.9 \\
\hline High & 24 & 8.2 \\
\hline Very High & 6 & 2.0 \\
\hline \multicolumn{3}{|l|}{ Social Security Status } \\
\hline No & 43 & 14.7 \\
\hline Yes & 250 & 85.3 \\
\hline Presence of Health Problem & & \\
\hline
\end{tabular}




\begin{tabular}{|l|c|c|}
\hline No & 258 & 88.1 \\
\hline Yes & 35 & 11.9 \\
\hline \multicolumn{2}{|l|}{ Status of Receiving Treatment (n:35) } \\
\hline I did not receive treatment & 5 & 14.3 \\
\hline I received treatment & 19 & 54.3 \\
\hline I still receive treatment & 11 & 31.4 \\
\hline Success Status & \multicolumn{2}{|l|}{} \\
\hline Poor & 6 & 2.0 \\
\hline Intermediate & 118 & 40.3 \\
\hline Good & 143 & 48.8 \\
\hline Very Good & 26 & 8.9 \\
\hline Total & 293 & 100 \\
\hline
\end{tabular}

Assessment of PRS and PSI Sub-Dimensions According to Sociodemographic Characteristics of Students

A statistically significant relationship was found out between age and PRS-C $(\mathrm{p}<0.05)$. According to Post-Hoc Tukey test, this significance was found to be between 18-20 age group and 24 and above age group $(\mathrm{p}<0.05)$. A statistically significant relationship was detected among PRS-SC ( $<<.001)$, PRS-C $(\mathrm{p}<0.01)$, PRS-CH $(\mathrm{p}<0.01)$, PSI-PSC $(\mathrm{p}<.001)$ and PSI-MAA $(\mathrm{p}<.001)$ save class in which students study and PSI-PC. It was found out according to the Post-Hoc Tukey test result that significance for PRS-SC was between 1st- 4th grades. There was not statistically significant difference for PSI-PC.

A statistically significant relationship between family type and PRS-SC $(\mathrm{p}<.001)$, PRS-CH $(\mathrm{p}<0.05)$, PSI-PSC $(\mathrm{p}<0.01)$ and PSI-PC $(\mathrm{p}<0.01)$ was also achieved. There was not a statistically significant difference between family type and PRS-C( $p>0.05)$, PSI-MAA ( $p>0.05)$. It was found out according to Post-Hoc Tukey result that there was a significant difference between single-parent family and nuclear family $(\mathrm{p}<.001)$; between single-parent family and extended family $(\mathrm{p}<.001)$ related to PRS-SC; between single-parent family and nuclear family $(\mathrm{p}<0.05)$ in terms of PRS-CH; between single-parent family and nuclear family $(\mathrm{p}<0.05)$ for PSI-PSC; between single-parent family and nuclear family $(\mathrm{p}<0.01)$ regarding PSIPC.

A statistically significant difference was achieved among family's interest and intimacy and PRS-SC $(\mathrm{p}<0.05)$, PRS-CH $(\mathrm{p}<0.05)$, PSI-PSC $(\mathrm{p} \leq .005)$ and PSIMAA $(\mathrm{p}<0.01)$ when considering in terms of family attitude. There was not a statistically significant difference for PRS-C and PSI-PC. Although significance was found out for PRS-SC according to Post-Hoc Tukey results, difference between the groups was not detected. It was also achieved that significances found between the 
ones whose family interest and intimacy is poor and very good ones for PRS-CH was $(\mathrm{p}<0.05)$, between the ones whose family interest and intimacy is poor and good ones was $(\mathrm{p}<0.05)$ and $(\mathrm{p}<0.01)$ for very good ones regarding PSI-PSC; finally, between the ones whose family interest and intimacy was poor and good ones was $(\mathrm{p}<0.05)$ and $(\mathrm{p}<0.05)$ for very good ones concerning PSI-MAA.

A statistically significant relationship was found between the accommodation characteristics of students and PRS-CH and PSI-MAA. According to Post-Hoc Tukey test results, difference was detected between staying with friends at home and staying with relatives at home $(\mathrm{p}<0.01)$ for PRS-C, difference for PSI-MAA was found between staying at home with friends and staying in dormitories $(p<0.05)$.

While a positive relationship among health problem and PRS-SC $(\mathrm{p}<0.05)$ and PRS-CH $(\mathrm{p}<0.05)$ was found, a negative relationship was achieved with PSI-MAA $(\mathrm{p}<0.05)$. There was a statistically significant relationship among status of receiving treatment and PRS-SC $(\mathrm{p}<0.05)$ and PRS-CH $(\mathrm{p}<.001)$. Any statistically significant difference was not found among PRS-C, PSI-PSC, PSI-MAA, PSI-PC and status of receiving treatment. According to the Post-HocTukey result, difference between the ones not receiving treatment and the ones receiving treatment was $(\mathrm{p}<0.05)$ for PRS-SC; difference between the ones not receiving treatment and the ones receiving treatment was $(\mathrm{p}<.001)$ for PRS-CH and $(\mathrm{p}<0.05)$ between the ones receiving treatment and still receiving treatment.

A statistically significant difference was found among success status and PRSSC $(\mathrm{p}=.001)$, PRS-CH $(\mathrm{p}<0.05)$, PSI-PSC $(\mathrm{p}<0.05)$ and PSI-MAA $(\mathrm{p}<0.05)$. According to Post-Hoc Tukey results, significances were achieved between the ones stating their success status as intermediate and good for PRS-SC $(\mathrm{p}=.001)$; between the ones stating their success status as good and very good for PRS- $\mathrm{CH}(\mathrm{p}<0.05)$; between the ones stating their success status as good and very good for PSI-PSC $(\mathrm{p}<0.05)$; between the ones stating their success status as intermediate and good for PSI-MAA $(\mathrm{p}<0.05)$ (Table 2). 


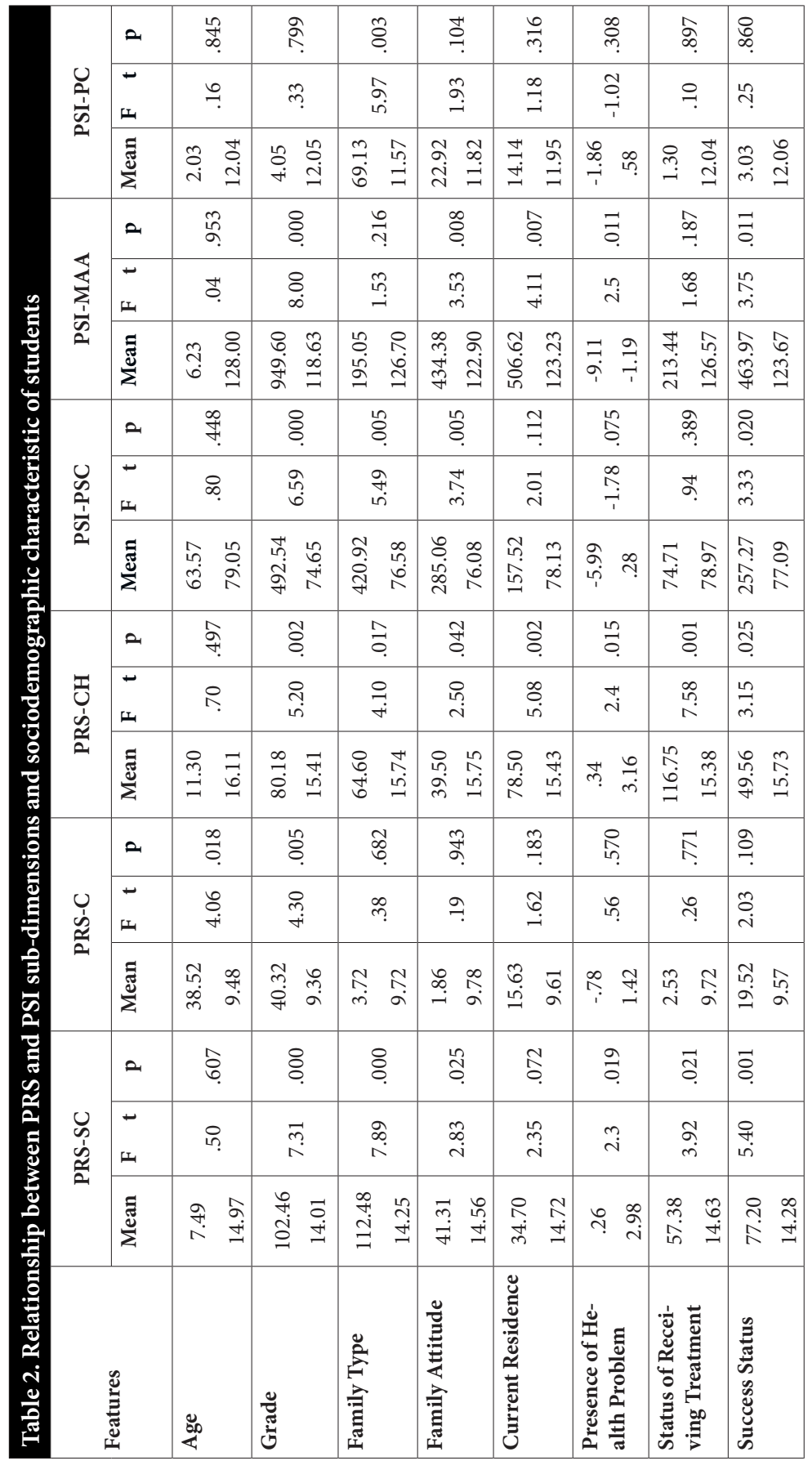


The Relationship Among PRS, Its Sub-Dimensions and PSI, and Sub-Dimensions

According to the Pearson correlation test administrated in order to determine the relationship between the subscales of PRS and PSI. There was a positive and poor relationship among PRS-SC, PRS-C and PRS-CH; a negative, poor and significant relationship was found among PSI-PSC, PSI-MAA and PSI-PC $(p<.001)$. There was a negative and very poor relationship between PRS-C and PSI-PSC $(\mathrm{p}<.001)$; a negative and poor relationship between PRS-C, PSI-MAA $(\mathrm{p}<.001)$ and PSI-PC $(\mathrm{p}<.05)$.

There was a negative and very poor relationship between PRS-CH, PSI-PSC $(\mathrm{p}<.001)$ and PSI-PC $(\mathrm{p}<.05)$, a negative and poor relationship between PRS-CH and PSI-MAA $(\mathrm{p}<.001)$. There was a positive and moderate relationship between PSI-PSC and PSI-MAA ( $\mathrm{p}<.001)$ and a positive, poor and significant relationship between PSI-PSC and PSI-PC $(\mathrm{p}<.001)$. There was a positive, poor and significant relationship between PSI-MAA and PSI-PC ( $\mathrm{p}<.001)$ (Table 3$)$.

Tablo 3. The relationship among PRS, its sub-dimensions and PSI, and sub-dimensions

\begin{tabular}{|c|c|c|c|c|c|c|c|}
\hline & & PRS-SC & PRS-C & PRS-CH & PSI-PSC & PSI-MAA & PSI-PC \\
\hline \multirow{3}{*}{ PRS-SC } & \multirow{3}{*}{$\begin{array}{l}\mathbf{r} \\
\mathbf{p} \\
\mathbf{N}\end{array}$} & 1 & $.42^{* *}$ & $.47^{\star *}$ & $-.30^{* *}$ & $-.34^{* *}$ & $-.31^{\star *}$ \\
\hline & & & .000 & .000 & .000 & .000 & .000 \\
\hline & & 293 & 293 & 293 & 293 & 293 & 293 \\
\hline \multirow{3}{*}{ PRS-C } & \multirow{3}{*}{$\begin{array}{l}\mathbf{r} \\
\mathbf{p} \\
\mathbf{N}\end{array}$} & & 1 & $.47^{\star *}$ & $-.23^{\star \star}$ & $-.26^{\star *}$ & $-.13^{\star}$ \\
\hline & & & & .000 & .000 & .000 & .021 \\
\hline & & & 293 & 293 & 293 & 293 & 293 \\
\hline \multirow{3}{*}{ PRS-CH } & \multirow{3}{*}{$\begin{array}{c}\mathbf{r} \\
\mathbf{p} \\
\mathbf{N}\end{array}$} & & & 1 & $-.24^{\star *}$ & $-.34^{\star *}$ & $-.13^{\star}$ \\
\hline & & & & & .000 & .000 & 0.17 \\
\hline & & & & 293 & 293 & 293 & 293 \\
\hline \multirow{3}{*}{ PSI-PSC } & \multirow{3}{*}{$\begin{array}{l}\mathbf{r} \\
\mathbf{p} \\
\mathbf{N}\end{array}$} & & & & 1 & $.68^{* *}$ & $.34^{\star *}$ \\
\hline & & & & & & .000 & .000 \\
\hline & & & & & 293 & 293 & 293 \\
\hline \multirow{3}{*}{$\begin{array}{l}\text { PSI- } \\
\text { MAA }\end{array}$} & \multirow{3}{*}{$\begin{array}{l}\mathbf{r} \\
\mathbf{p} \\
\mathbf{N}\end{array}$} & & & & & 1 & $.37^{* *}$ \\
\hline & & & & & & & .000 \\
\hline & & & & & & 293 & 293 \\
\hline \multirow{2}{*}{ PSI-PC } & $\mathbf{r}$ & & & & & & 1 \\
\hline & $\stackrel{\mathbf{p}}{\mathbf{N}}$ & & & & & & 293 \\
\hline
\end{tabular}

* Correlation is significant (p) at the .05 level (2-tailed).

${ }^{\star *}$ Correlation is significant $(\mathrm{p})$ at the .01 level (2-tailed).

***Psychological Resilience Scale (PRS): Self-Commitment (PRS-SC), Control (PRS-C) and Challenging (PRS-CH); Problem Solving Inventory (PSI): Problem Solving Confidence (PSI-PSC), The Manner of Approach-Avoidance (PSI-MAA), Personal Control (PSI-PC) 


\section{Multiple Regression Analysis of Predictor of PRS Score}

PSI was found to be a significant predictor of PRS ( $\mathrm{R}=-.41, \mathrm{R} 2=.17, \mathrm{~F}=59.37$, $\mathrm{p}<.001)$ in the analysis of $\mathrm{t}$-test administrated for the significance of regression coefficients (Table 4).

\begin{tabular}{|l|c|}
\hline \multicolumn{2}{|c|}{ Tablo 4. Multiple regression analysis of predictor of PRS score } \\
\hline \multicolumn{2}{|c|}{ Model $\mathbf{B}$} \\
\hline Problem Solving Inventory & -0.41 \\
\hline $\mathbf{R}^{\mathbf{2}}$ & 0.17 \\
\hline $\mathbf{t}$ & -7.70 \\
\hline $\mathbf{p}$ & .000 \\
\hline
\end{tabular}

\section{DISCUSSION}

The results of this study examining the problem-solving skills and resilience of university students were discussed in the light of the literature.The correlation coefficient between the score averages of the subscales of PRS and PSI was in significant level. Accordingly, there is a positive relationship between PRS and PSI, and it explains $17 \%$ of the effect of problem-solving on resilience. While students with high resilience level use active coping strategies with their problem-solving skills, individuals with low resilience level feel themselves incapable in their problem-solving skills and use the strategy of avoidance coping. According to Earvolino Ramirez (2007), problem solving skill is the ability to overcome the difficulties encountered in reaching the goal. In the literature, it is emphasized that one of the important variables affecting psychological resilience is problem solving skills (Durmuş ve Okanl1, 2018). Problem solving skill is defined as the reflection of both internal and external desires to mental behavior. The person's needs, beliefs, abilities and behaviors are related to problem solving in achieving her/his goal.

A significant relationship was found out between the score average of PRS-C and age, and it was determined that this significance was between 18-20 age group and 24 and above age group. Similarly, SossahandAsiedu's (2015) study found that nursing students aged 24 years and above had higher resilience. It was also determined that especially in the last period of university life with increasing education level and age, students could develop their abilities such as individual autonomy, self-discipline, decision-making skills etc. It can be urged as a result of this research that age of individual is an important concept affecting resilience and individual pays attention to his/her own needs and emotions in increasing the resilience, think positively for the future, has self-confidence, turns this into an opportunity after every difficulty and maintains good relations with his/her surrounding (Wag- 
nild, 2009).

In our study, any significant relationship was not found between "age", one of the individual characteristics of students, and the average scores of the sub-dimensions of problem-solving inventory. Similar to our study, some studiesfound no statistically significant difference between age and problem-solving skills of students (Durmaz et al., 2018; Yenice et al., 2012). Similar conclusions were obtained in a different study conducted in parallel to this result (Erol et al., 2016; Başar et al., 2015). This result was found to be significant in terms of re-evaluation of nursing curriculum and strengthening problem-solving and effective coping skills of students especially in the context of lifelong learning principles.

It was found to be a significant relationship between family types and PRS and PSI subscales. Accordingly, within single-parent, nuclear and extended family types, challenging, self-commitment and problem-solving confidence and personal control of especially single-parent students increase. This conclusion indicates that students with single parents without having parents or other relatives have more tendency in getting interested in various areas of life, devoting themselves to social, work, family environments, interpersonal relations, beliefs and values, and this shows that students have problem solving confidence in order to cope with stressful life situations.

When examining how individuals participating in this study perceived the attitudes of their families towards them, any relationship was not only found between the sub-dimensions of PRS-C and PSI-PC, however, a statistically significant relationship was found between all other dimensions.In a study carried out by Thomas and Revell (2016), factors affecting resilience were grouped into three categories: time, support, and empowerment. In this context, support from family, friends and faculty impact a student's resilience. The support obtained by the individual within the family causes him/her to take control of the stressful situation and its possible negative consequences, and to look at the future with hope by providing him/her with the feeling that $\mathrm{s} /$ he is not alone in the face of problems.

In this study, when the problem-solving skills and resilience levels of students staying at home or in the dormitory were investigated, it was achieved that resilience and problem-solving skills were higher in favour of the students staying in dormitories. Similar results were also suggested in a study (Olgun ve ark., 2010). This conclusion led to the idea that the self-confidence of individuals taking the responsibility of life alone increased, they gained the courage to face their problems and thus could solve their problems.According to the conclusions obtained from the study, individuals with a high level of problem-solving skills and resilience express a higher level of success in their academic lives than others. 
In our study, students with health problems and receiving treatment have difficulty in adopting an active attitude for different alternative solutions to their problems. On the other hand, it can be urged that they are trying to protect themselves psychologically by devoting themselves to their social environments, families, interpersonal relations, belief system and values and believing that they can reorganise situations they have lived. This result can be explained in the context of Neuman's System Theory. According to Neuman,humanbeing is in constant interaction with the environment, in order to achieve harmony and balance, internal and externalis in constant interaction with the environment and try to balance her/ himself against negative stimulans like diseases (Fawcett, 2005).

\section{CONCLUSION}

In the light of these results, it may be suggested to plan training to increase students' problem-solving skill methods and resilience, and to increase psychological counselling services to guide problems of students that they encounter. Resilience programs that includes problem solving methods and mindfulness issues could be implemented in the nursing curriculum. Academic awareness about resilience of nursing students can better prepare for the role of professional nurse. In conclusion, it is recommended to carry out similar studies with larger sample groups, nursing students in different regions and students in different departments, and compare these conclusions, and to conduct studies examining the relationship among resilience and other risk factors, protective factors and positive outcome criteria.

It is of important that nurse educators and school administrators plan activities such as mentoring and group education sessions, plan psychological counselling and training programs, set clear organizational strategies to increase students' problem-solving skill methods and resilience. In this respect, department of faculty management and faculty members should In conclusion. This study will contribute to the practices to be conducted for determining risk factors of nursing students in psychological respects, identifying individual protective factors and gaining/developing these factors.

\section{Acknowledgement}

The authors of the research express their gratitude to the participants. No support was received from any project or company related to the research.

\section{Conflict of Interest}

The authors reported no conflict of interest. 


\title{
Authorship Contributions:
}

\author{
Concept/Design: ME
}

Data collection: GY

Data Analysis and/or interpretation: GY, ME, YYU

Writing:ME, GY

Critical review: ME, GY, YYU

\section{REFERENCES}

Ançel, G. (2016). Problem-solving training: Effects on the problem-solving skills and self-efficacy of nursing students. Eurasian Journal of Educational Research, 64, $231-246$.

Arslan, G. (2015). Çocuk ve genç psikolojik sağlamlık ölçeği'nin (ÇGPSÖ-12) psikometrik özellikleri: Geçerlilik ve güvenirlik çalışması. Ege Eğitim Dergisi, 16(1), 1-12.

Asimopoulos, C., Martinaki, S., \& Maniadaki, K. (2018). Problem-solving skills and mental health of social work students in Greece. The Journal of Social Sciences Research, 4(11), 220-228.

Atasoy, I., Sütütemiz, N. (2014). Bir grup hemşirelik son sınıf öğrencisinin hemşirelik eğitimi ile ilgili görüşleri. Florence Nightingale Journal of Nursing, 22(2), 94-104.

Başar, G., Akın, S., \& Durna, Z. (2015). Evaluation of problem solving and communication skills in nurses and nursing students. Gümüşhane University Journal of Health Sciences, 4(1), 125-147.

Bayındır, C. A., \& Olgun, N. (2015). Do problem-solving skills affect success in nursing process applications? An application among Turkish nursing student. International Journal of Nursing Knowledge, 26(2), 90-95.

Çelikkalp, Ü., Aydın, A., ve Temel, M. (2010). Bir sağılk yüksekokulu hemşirelik bölümü öğrencilerinin aldıkları eğitime ilişkin görüş̧leri. Maltepe Üniversitesi Hemşirelik Bilim ve Sanatı Dergisi, 3(2), 2-14.

Durmaz, Y. Ç., Serin, E. K., \& Polat, H. T. (2018). Determination of problem-solving and communication skills of nursing/midwifery students. International Journal of Caring Sciences, 11(3), 1772-1777.

Durmuş, M., Okanlı, A. (2018). Üniversite öğrencilerinin problem çözme becerileri ile psikolojik dayaniklilik düzeylerinin değerlendirilmesine yönelik bir araştırma. Yaşam Becerileri Psikoloji Dergisi, 2(4), 177-189.

Earvolino-Ramirez, M. (2007). Resilience: A concept analysis. Nursing Forum, 42, 73-82.

Ergöl, Ş., Kürtüncü, M. (2013). Hemşirelik öğrencilerinin uygulama alanlarında karşısştıkları şiddet. Yükseköğretim ve Bilim Dergisi, 3(1), 65-69.

Erol, F., Tanrikulu, F., Dikmen, Y., \& Akduran, F. (2016). Examination of problem solving skills of nursing students in terms of some variables. Journal of Human Sciences, 13(3), 5460-5470.

Fawcett, J. (2005). Contemporary Nursing Knowledge: Analysis and Evaluation of Nursing Models and Theories. Philadelphia: FA. Davis Company.

Ghosh, M., \& Sobek, D. K. (2015). A problem-solving routine for improving hospital operations. Journal of Health Organization and Management, 29(2), 252-270.

Gündaş, A., Koçak, R. (2015). Lise öğrencilerinde psikolojik sağlamlığın yordayııısı olarak benlik kurgusu. Uluslararası Sosyal Araştırmalar Dergisi, 8(41), 795-802.

Kelly, L. A., \& Lefton, C. (2017). Effect of meaningful recognition on critical care nurses' compassion fatigue. Am J Crit Care, 26(6), 438-444.

Kester, K., \& Holly, W. (2018). Building nurse resilience. Nursing Management, 49(6), 42-45.

Kılıç, ş. D. (2014). Üniversite Öğrencilerinin Yalnızlık ve Psikolojik Dayanıklılılarının Incelenmesi. Eğitim Bilimleri Anabilim Dalı. Yüksek Lisans Tezi. Atatürk Üniversitesi Eğitim Bilimleri Enstirüsü, Erzurum.

Lopez, V., Yobas, P. K., Chow, Y. L., \& Shorey, S. (2018). Does building resilience in undergraduate nursing students happen through clinical placements? A qualitative study. Nurse Education Today, 67, 1-5. 
Meichenbaum, D. (2009). Bolstering Resilience: Benefiting From Lessons Learned. Danny Brom, Ruth PatHorenczyk, Julian D. Ford (Eds.), Treating Traumatized Children: Risk, Resilience And Recovery. (s. 183-192). New York: Routledge.

Ranjbar, M., Bayani, A. A., \& Bayani, A. (2013). Social problem solving ability predicts mental health among undergraduate students. International Journal of Preventive Medicine, 4(11), 1337-1341.

Schmidt, M., \& Haglund, K. (2017). Debrief in emergency departments to improve compassion fatigue and promote resiliency. Journal of Trauma Nursing, 24(5), 317-322.

Stephens, T. M. (2015). Nursing student resilience: A concept clarification. Nursing Forum, 48(2), 125-133.

Sossah, L., \& Asiedu, Y. (2015). Stress management and resilience in junior and senior nursing students in Ghana. European Journal of Research and Reflection in Educational Sciences, 3(2), 46-53.

Şahin, N., Şahin, N. H., \& Heppner, P. P. (1993). The psychometric properties of the problem solving inventory in a group of Turkish university students. Cognitive Therapy and Research, 17(4), 379-396.

Terzi, S.. (2016). Psikolojik dayanıkulık ölçeği'nin geliştirilmesi: Geçerlik ve güvenirlik çalışması. The Journal of Happiness \& Well-Being, 4(2), 165-182.

Thomas, D., Newcomb, P., \& Fusco, P. (2018). Perception of caring among patients and nurses. Journal of Patient Experience, 6(3), 194-200.

Thomas, L. J., \& Revell, S. M. H. (2016). Resilience in nursing students: an integrative review. Nurse Education Today, 36, 457-462.

Olgun, N., Öntürk, Z., Karabacak, Ü., Aslan, F., ve Serbest, ş. (2010). Hemşirelik öğrencilerinin problem çözme becerileri: Bir yıllık izlem sonuçları. Acıbadem Üniversitesi Sağlık Bilimleri Dergisi, 1(4), 188-194.

Wagnild, G. (2009). A review of the resilience scale. Journal of Nursing Measurement, 17(2), 105-113.

Yenice, N., Özden, B., \& Evren, B. (2012). Examining of problem solving skills according to different variables for science teachers candidates. Procedia-Social and Behavioral Sciences, 46, 3880-3884.

Yıldırım J. G., Calt A. C., \& Ardahan M. (2019). Problem-solving skills of university nursing students and factors affecting them: A Cross-sectional study. Journal of Pakistan Medical Association. 69(11):1717-1720. doi: 10.5455/ JPMA.2635. 